\title{
Evaluation and consideration of local specimen material properties in lifetime prediction of short fibre reinforced PA6T/6I
}

\author{
Gabriel Stadler ${ }^{1}$, Andreas Primetzhofer ${ }^{2}$, Gerald Pinter ${ }^{1}$, and Florian Grün ${ }^{1}$ \\ ${ }^{1}$ Montanuniversitat Leoben \\ ${ }^{2}$ Polymer Competence Center Leoben GmbH
}

December 8, 2021

\begin{abstract}
To exploit the full material potential of short fibre reinforced PA6T/6I, specific component calculations including aniso- tropic material behaviour is necessary. For this, different failure criteria and fatigue models are used to describe the behaviour during a component service life. This paper deals with the determination and consideration of fibre orientations for failure criteria and fatigue calculations. Therefore, a novel method to determine fibre orientation (FO) distributions across injection moulded plates, is proposed. The developed method allows a forecast of FOs for different specimen extraction positions and angles on injection moulded plates by using only a few measured reference points. As a result, fatigue models can be calibrated with the strength values and the corresponding FO, calculated for fracture position. The performed tests show a non-negligible influence of failure positions, due to fibre orientation distributions along the specimens. So, the FO determination method delivers an improvement in strength values estimation.
\end{abstract}

\section{Hosted file}

Evaluation and consideration of local specimen material properties in lifetime prediction of short fibr available at https://authorea.com/users/450175/articles/548553-evaluation-and-considerationof-local-specimen-material-properties-in-lifetime-prediction-of-short-fibre-reinforcedpa6t-6i

\section{Hosted file}

KNP_2mm_ungekerbt.pdf available at https://authorea.com/users/450175/articles/548553evaluation-and-consideration-of-local-specimen-material-properties-in-lifetimeprediction-of-short-fibre-reinforced-pa6t-6i 


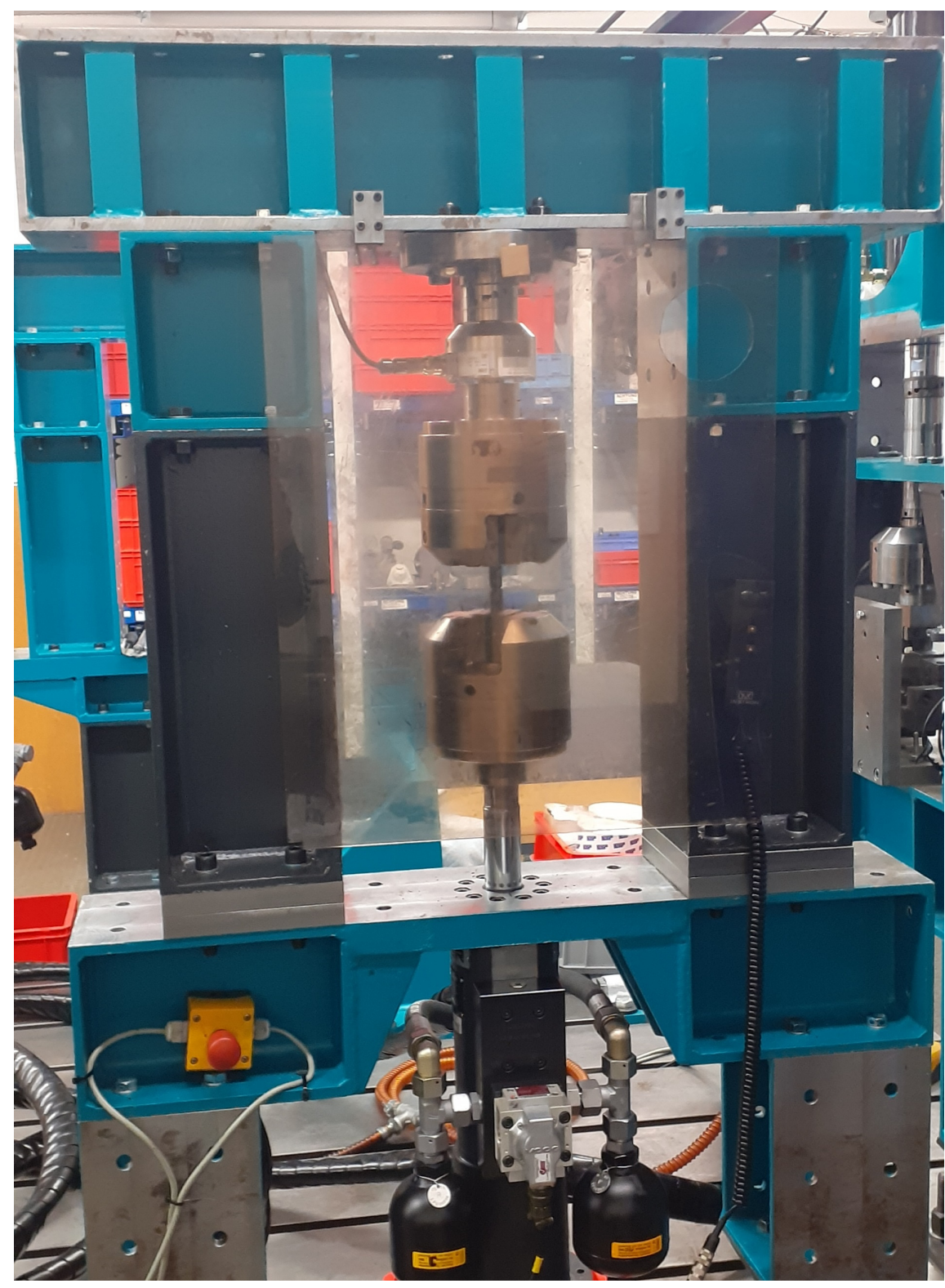

\section{Hosted file}

KNP_2mm_ungekerbt.pdf_tex available at https://authorea.com/users/450175/articles/548553evaluation-and-consideration-of-local-specimen-material-properties-in-lifetimeprediction-of-short-fibre-reinforced-pa6t-6i 

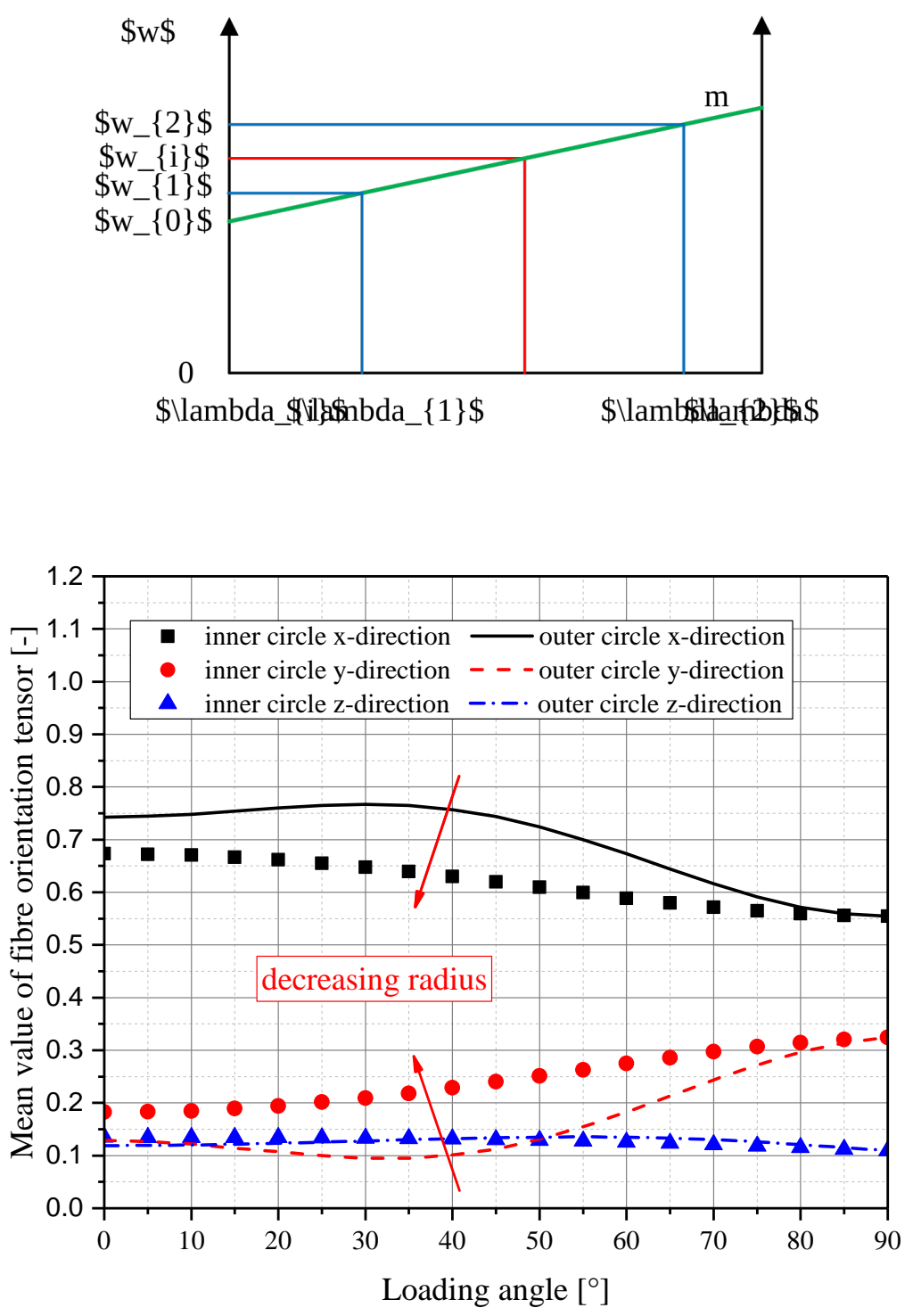

\section{Hosted file}

Testing_machine.pdf available at https://authorea.com/users/450175/articles/548553evaluation-and-consideration-of-local-specimen-material-properties-in-lifetimeprediction-of-short-fibre-reinforced-pa6t-6i 

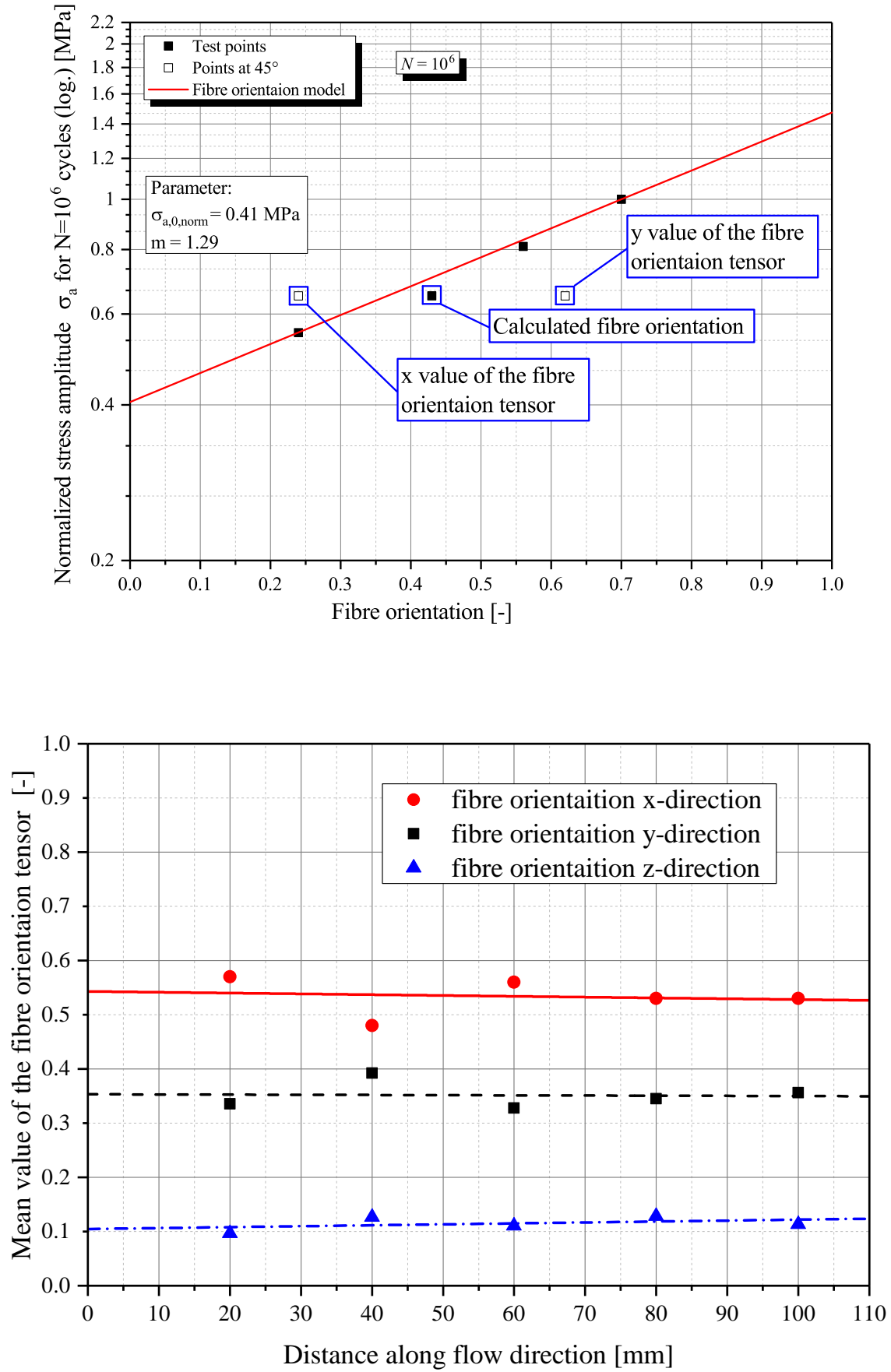

\section{Hosted file}

Gaier_model.pdf available at https://authorea.com/users/450175/articles/548553-evaluationand-consideration-of-local-specimen-material-properties-in-lifetime-prediction-of-shortfibre-reinforced-pa6t-6i 

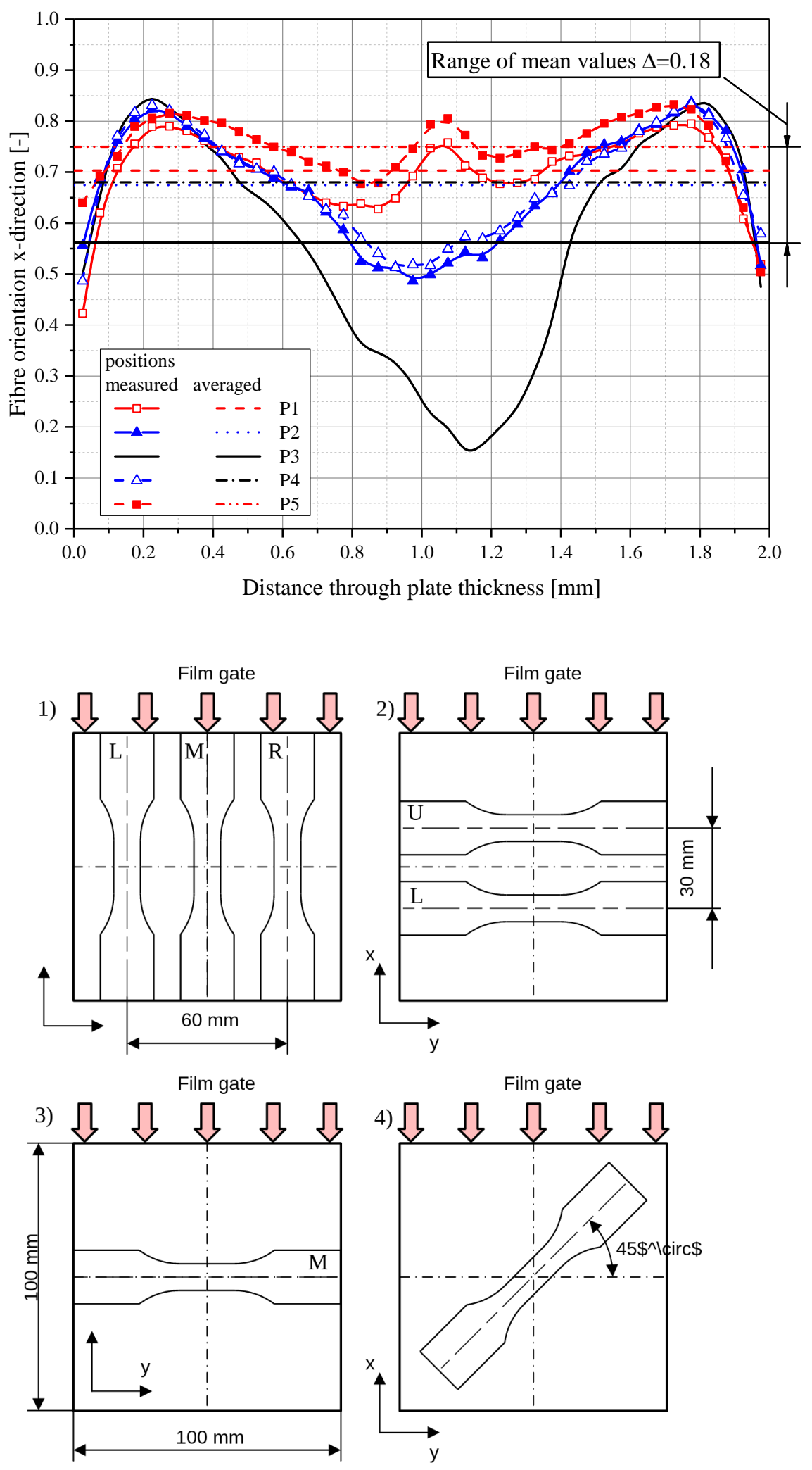


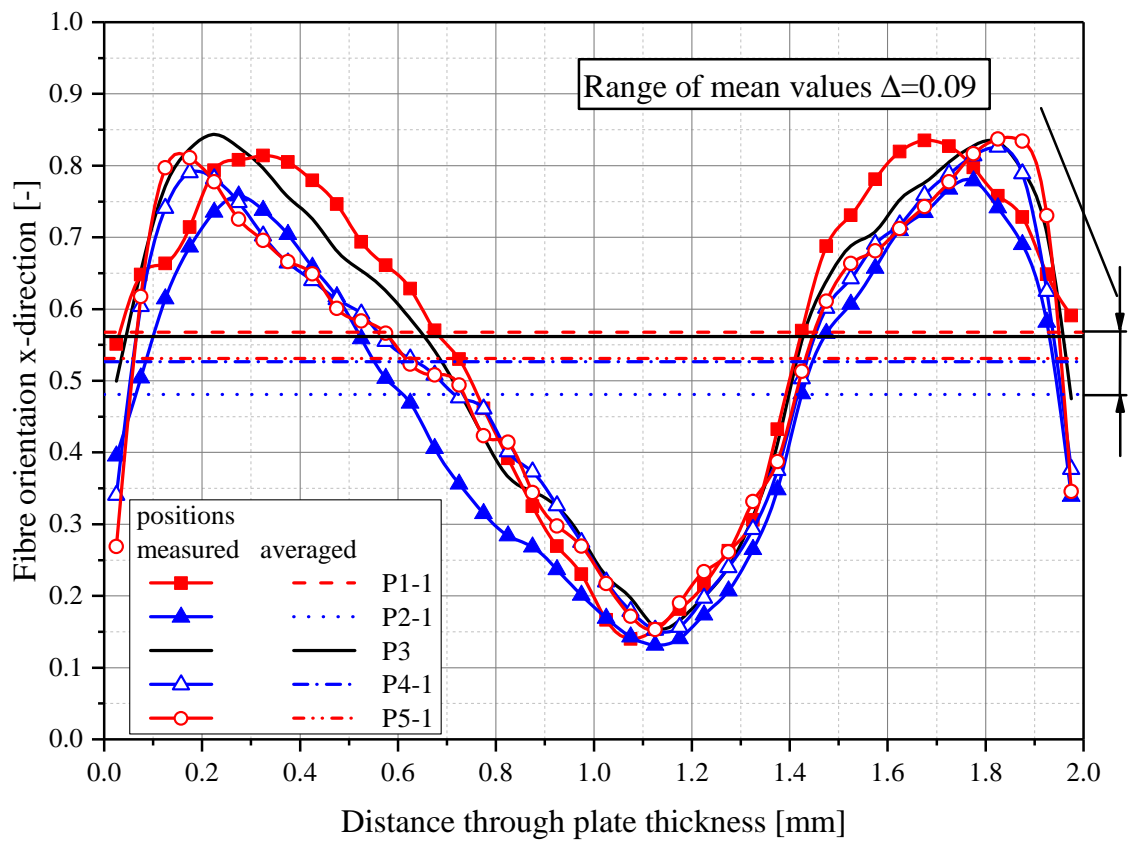




\section{$\times$ Point of fracture}

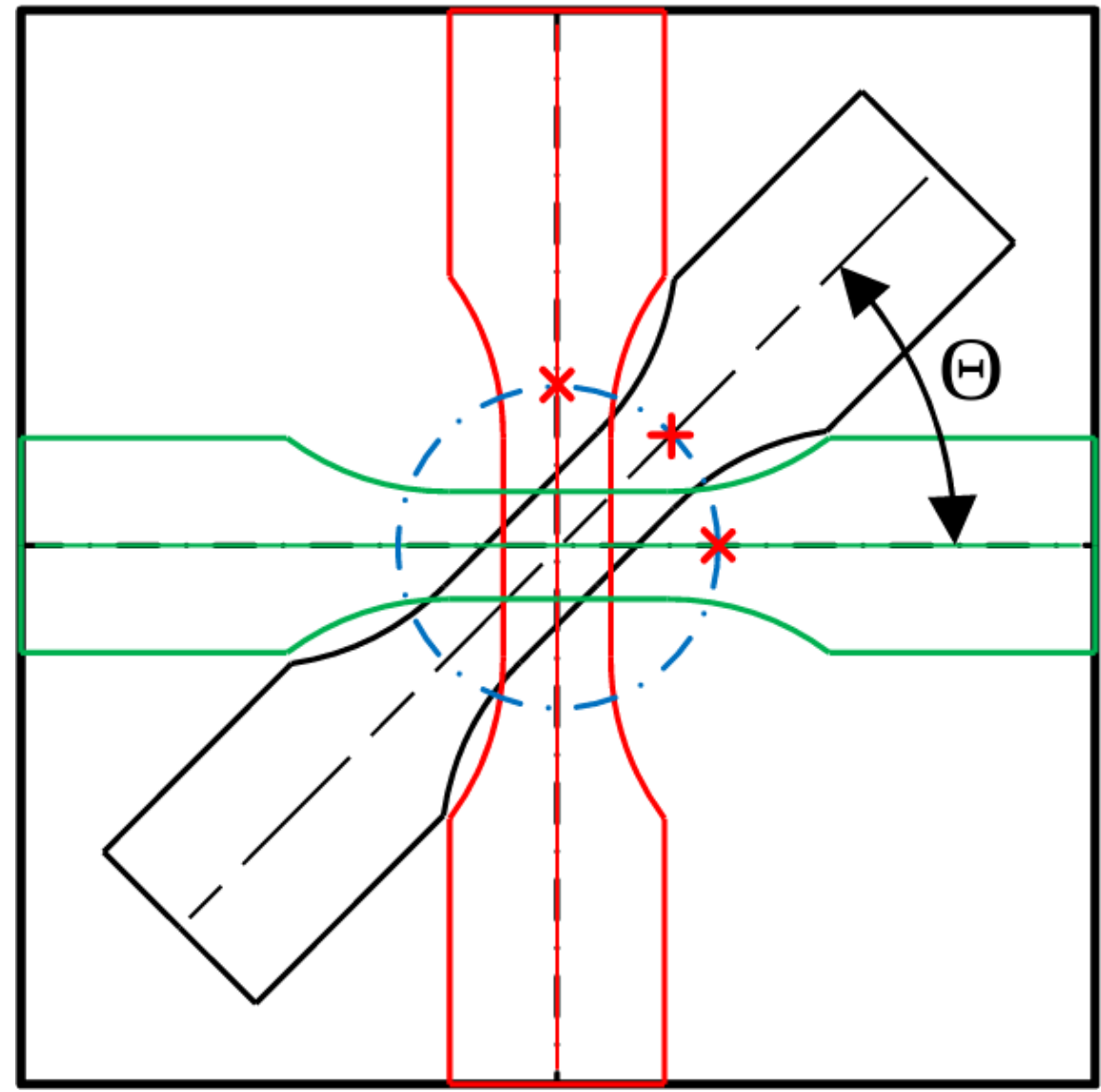

\section{Hosted file}

CT-Positions.pdf available at https://authorea.com/users/450175/articles/548553-evaluationand-consideration-of-local-specimen-material-properties-in-lifetime-prediction-of-shortfibre-reinforced-pa6t-6i

Hosted file

Gaier_model.pdf_tex available at https://authorea.com/users/450175/articles/548553evaluation-and-consideration-of-local-specimen-material-properties-in-lifetimeprediction-of-short-fibre-reinforced-pa6t-6i 
$\otimes \quad$ Positions of \$ \$mu\$CT-scans

$\otimes \quad$ Positions of calculated fibre orientations

$\rightarrow$ Loading direction

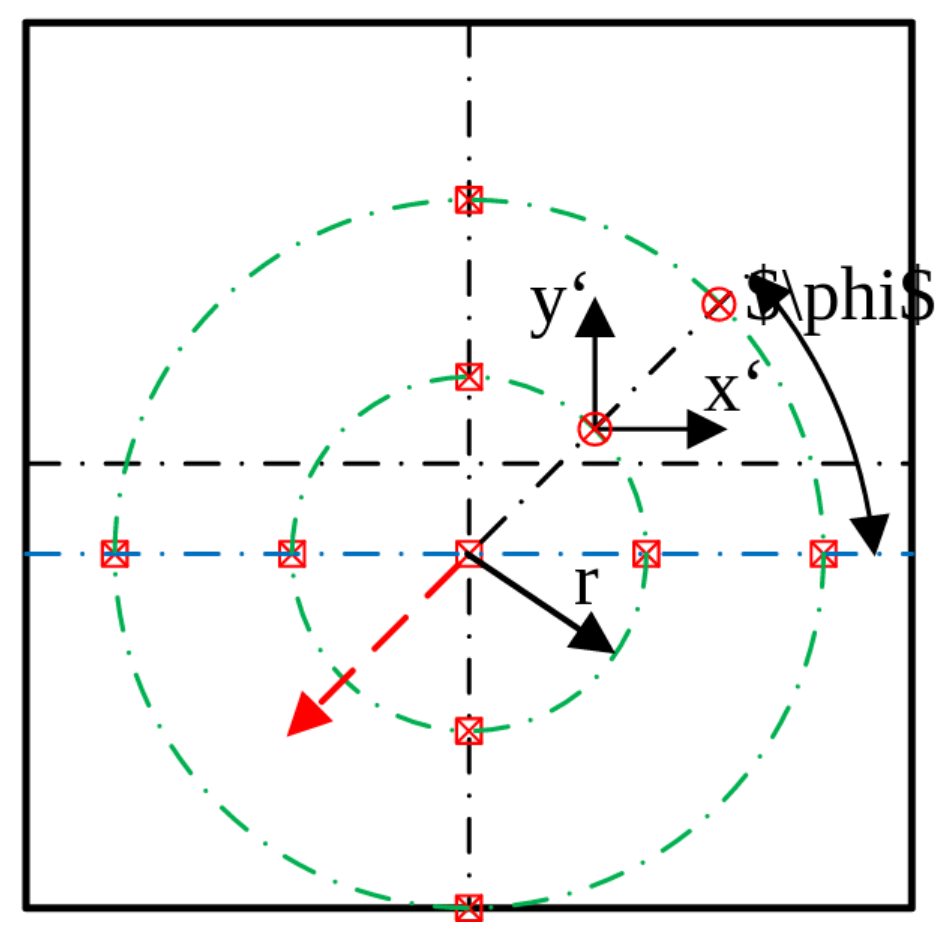

Hosted file

loading_plane.pdf available at https://authorea.com/users/450175/articles/548553-evaluationand-consideration-of-local-specimen-material-properties-in-lifetime-prediction-of-shortfibre-reinforced-pa6t-6i 

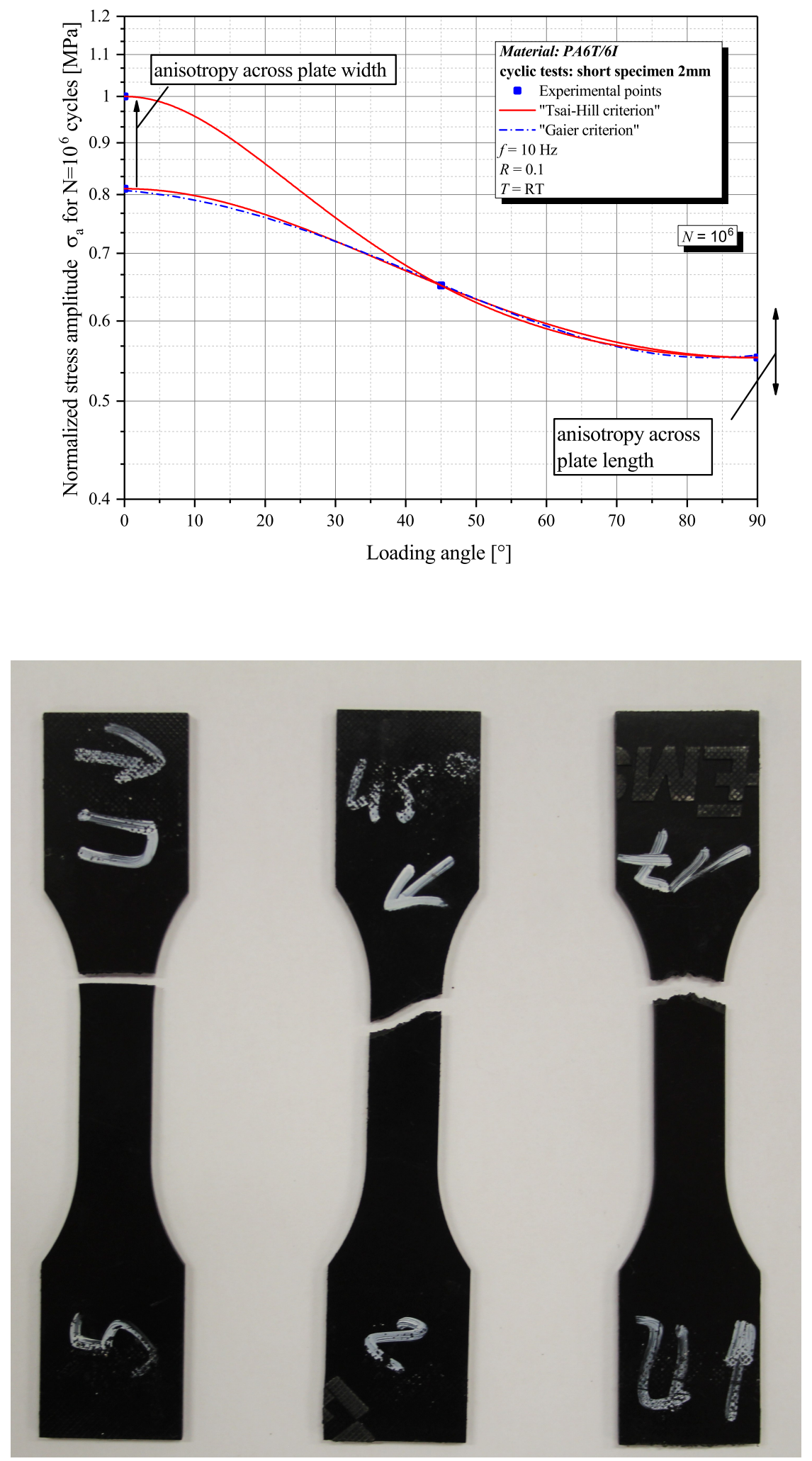


\section{Hosted file}

Points_of_fracture.pdf_tex available at https://authorea.com/users/450175/articles/548553evaluation-and-consideration-of-local-specimen-material-properties-in-lifetimeprediction-of-short-fibre-reinforced-pa6t-6i

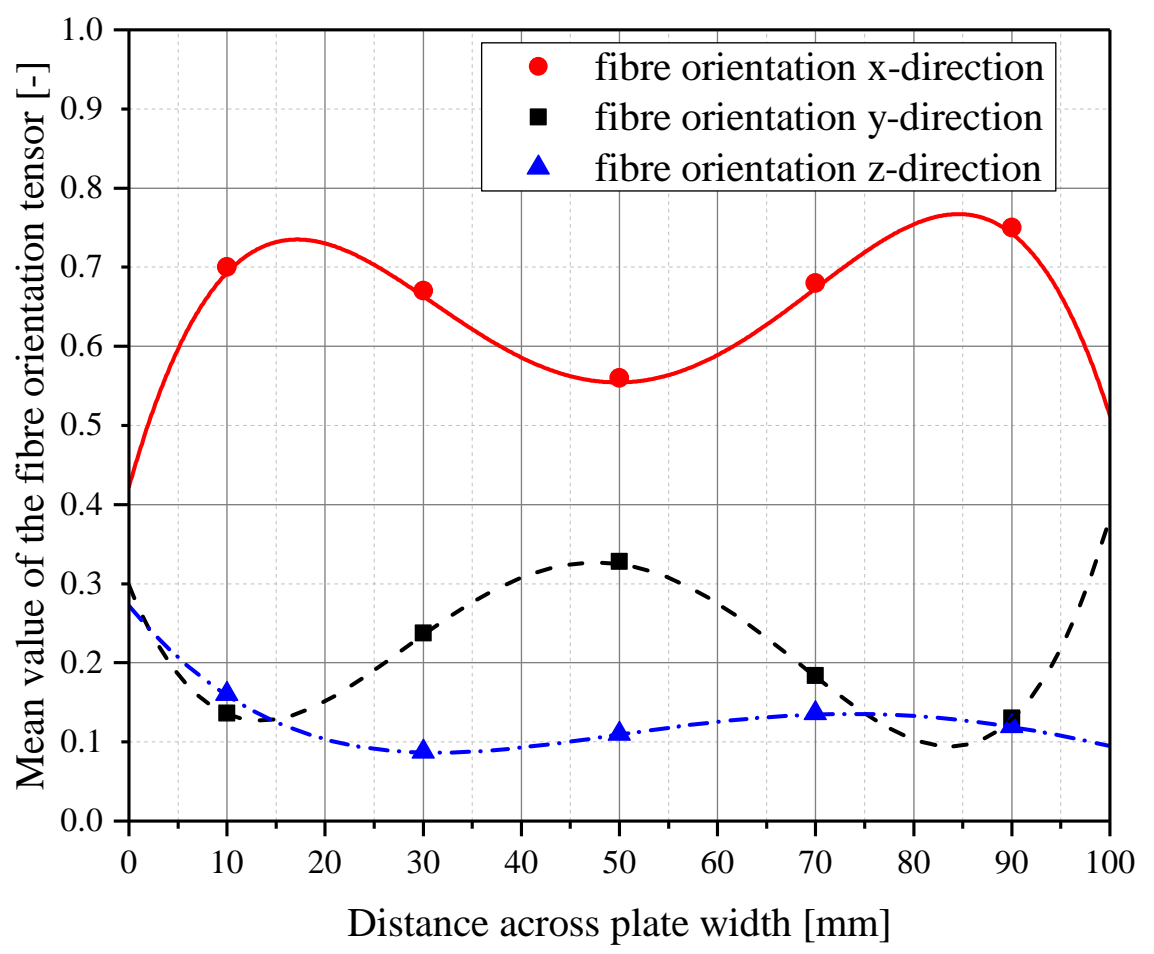




\section{$\otimes \quad$ Positions of \$ $\backslash$ mu\$CT-scans}

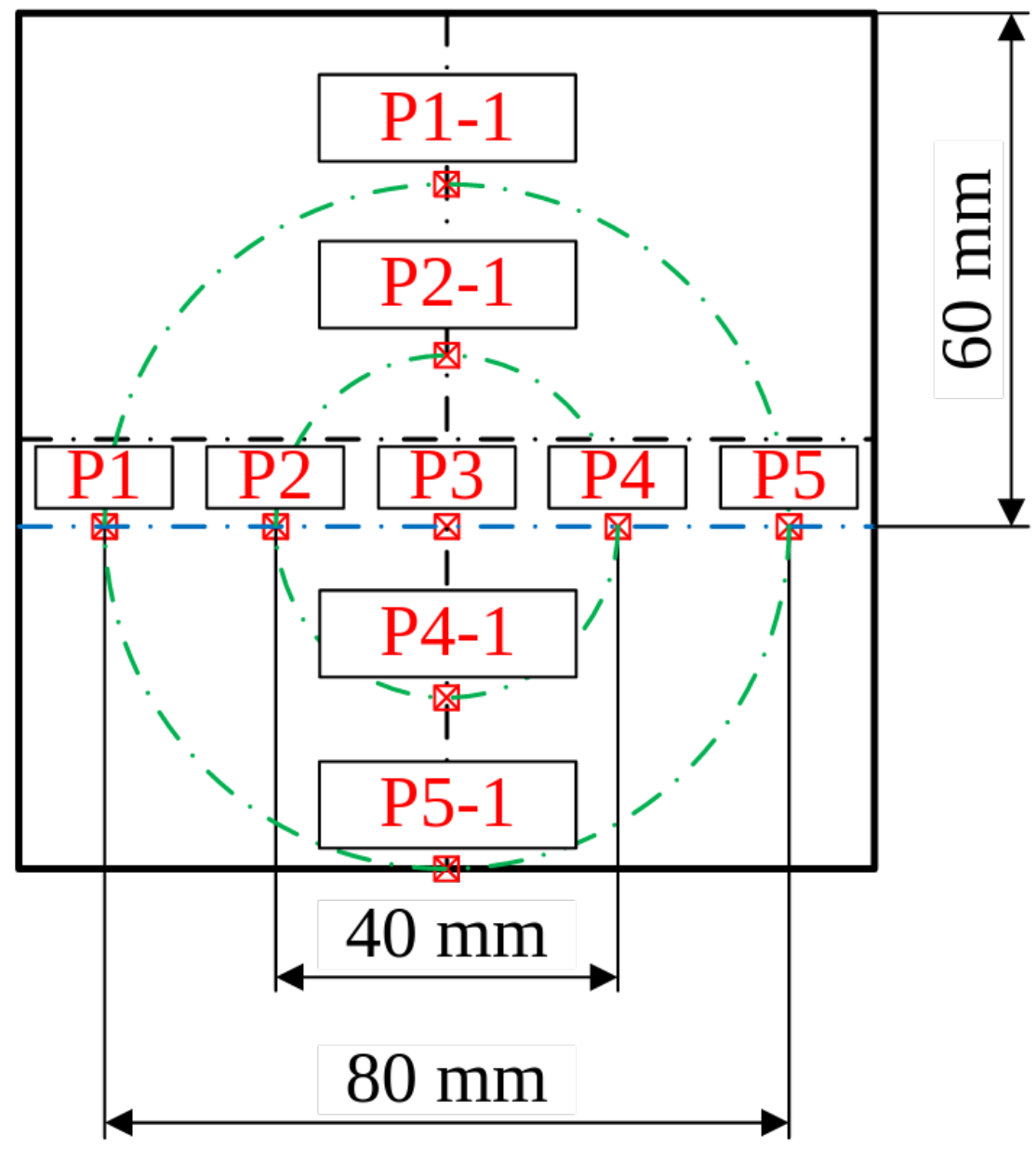

\section{Hosted file}

specimen.pdf_tex available at https://authorea.com/users/450175/articles/548553-evaluationand-consideration-of-local-specimen-material-properties-in-lifetime-prediction-of-shortfibre-reinforced-pa6t-6i

\section{Hosted file}

Points_of_fracture.pdf available at https://authorea.com/users/450175/articles/548553evaluation-and-consideration-of-local-specimen-material-properties-in-lifetimeprediction-of-short-fibre-reinforced-pa6t-6i 

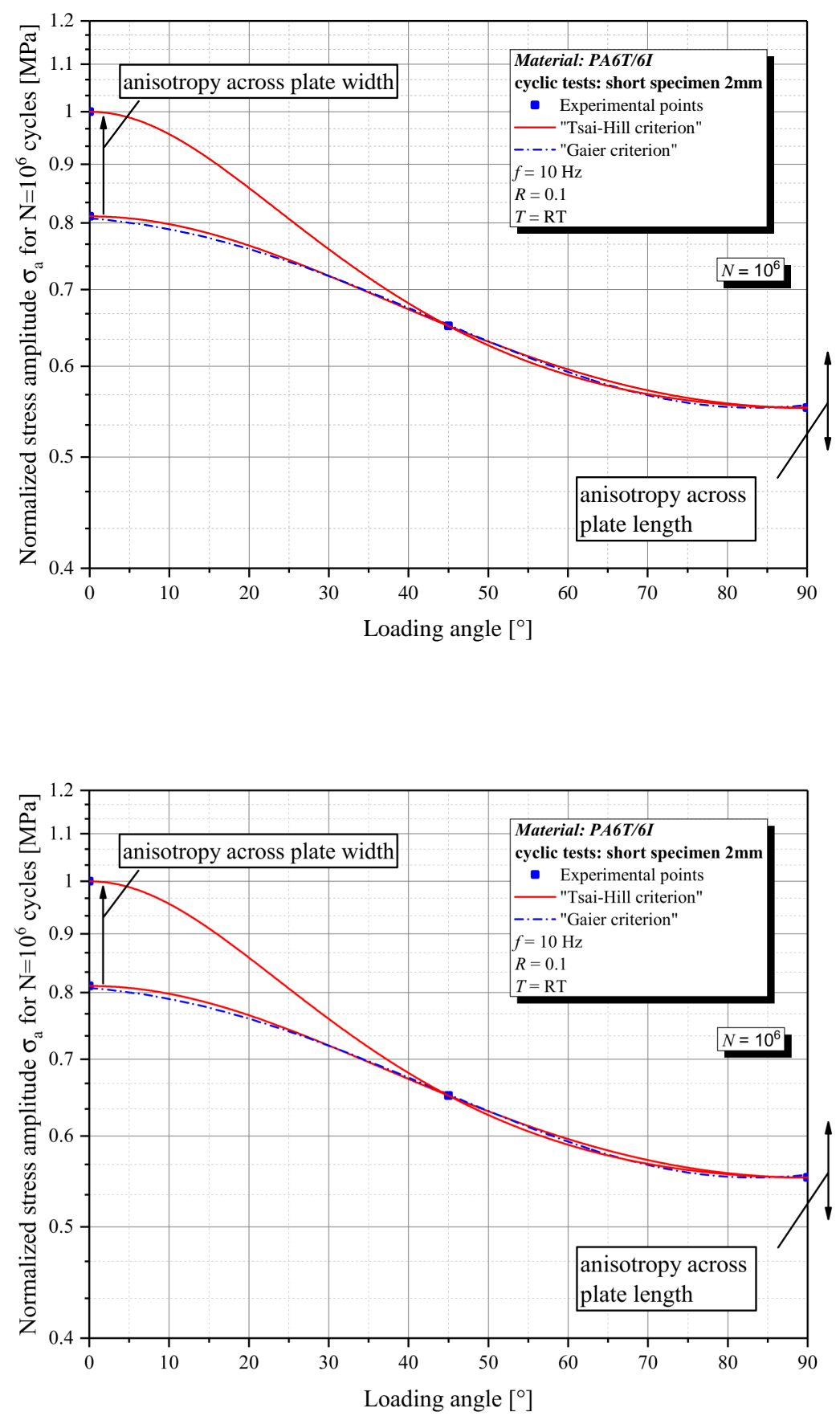

\section{Hosted file}

extraction_position.pdf_tex available at https://authorea.com/users/450175/articles/548553evaluation-and-consideration-of-local-specimen-material-properties-in-lifetimeprediction-of-short-fibre-reinforced-pa6t-6i

\section{Hosted file}


CT-Positions.pdf_tex available at https://authorea.com/users/450175/articles/548553evaluation-and-consideration-of-local-specimen-material-properties-in-lifetimeprediction-of-short-fibre-reinforced-pa6t-6i

figures/FO-model-cyclic/FO-model-cyclic-eps-converted-to.pdf 

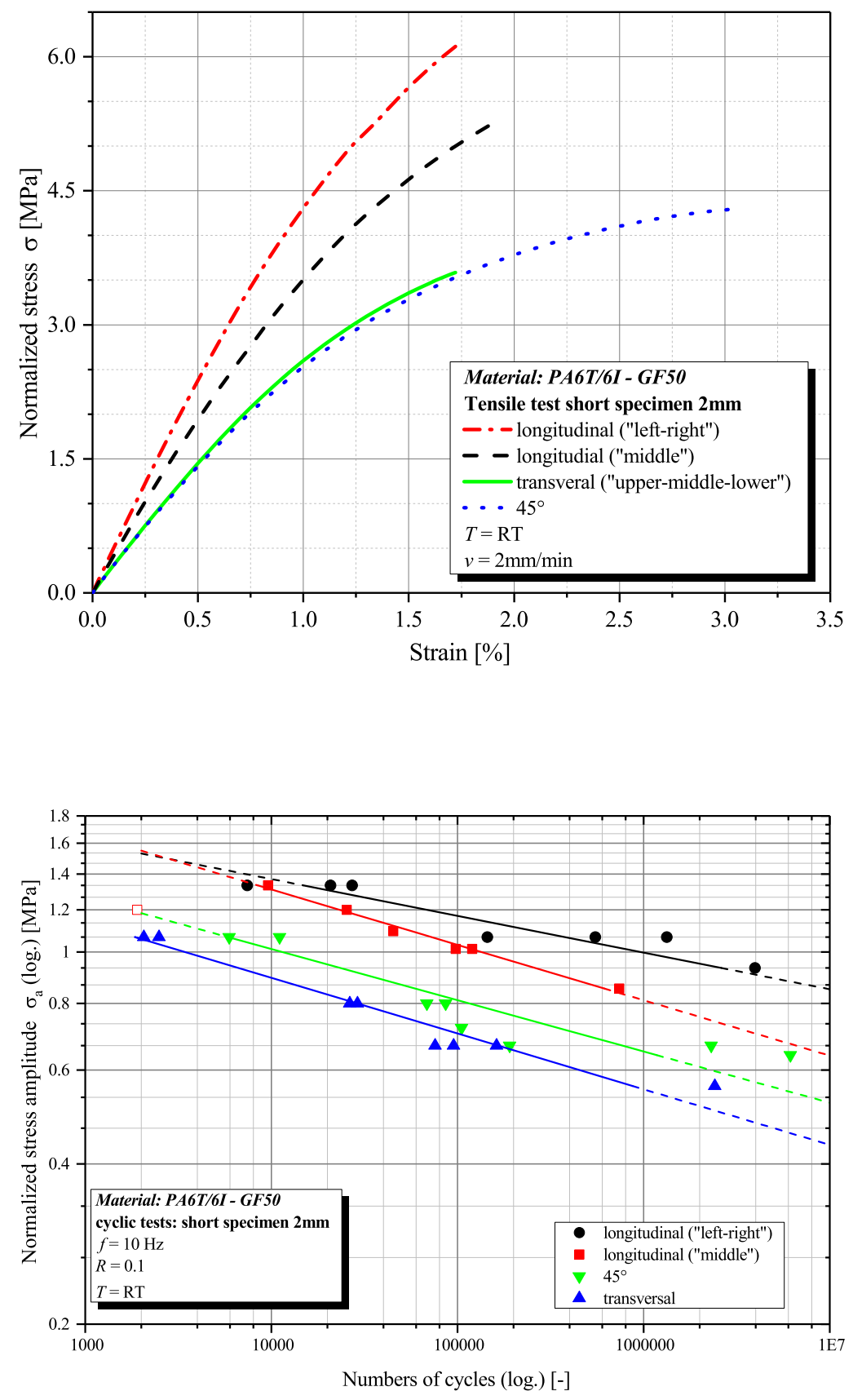

\section{Hosted file}

loading_plane.pdf_tex available at https://authorea.com/users/450175/articles/548553evaluation-and-consideration-of-local-specimen-material-properties-in-lifetimeprediction-of-short-fibre-reinforced-pa6t-6i 
figures/cyclic-tests/cyclic-tests-eps-converted-to.pdf

\section{Hosted file}

extraction_position.pdf available at https://authorea.com/users/450175/articles/548553evaluation-and-consideration-of-local-specimen-material-properties-in-lifetimeprediction-of-short-fibre-reinforced-pa6t-6i 
figures/tensile-test/tensile-test-eps-converted-to.pdf 


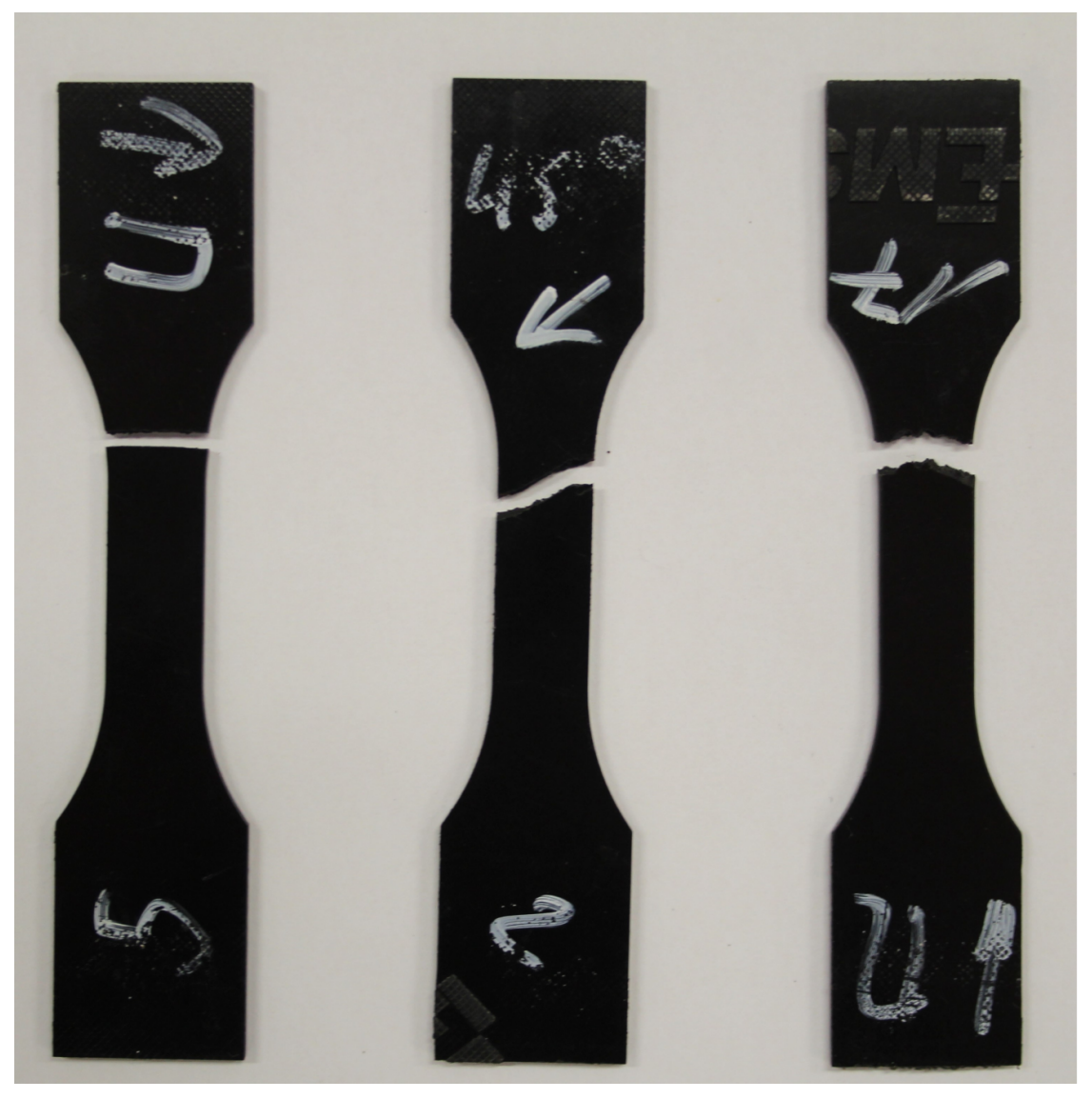

